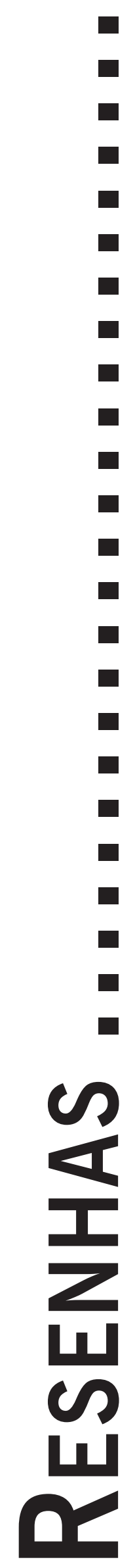




\title{
RESENHAS
}

\section{ENCONTRO: UMA ABORDAGEM HUMANISTA, 2004}

\author{
(Clara Feldman) \\ Belo Horizonte: Crescer \\ THAis Ribari FUJIOKA \\ Instituto de Treinamento e Pesquisa em Gestalt-Terapia de Goiânia (ITGT)
}

A escritora e psicóloga Clara Feldman, em seu mais recente livro, Encontro - uma abordagem humanista (2004) chama a atenção para a grandiosidade e o enigma de relacionar-se à luz de uma perspectiva humanista. Desse modo, convida o leitor a refletir sobre as posturas internas, que podem ser expressas em habilidades que facilitam o relacionamento em qualquer condição.

O livro tem como finalidade prestar uma compreensão melhor do relacionamento humano, desvendar parte do mistério que o cerca e aumentar a chance de que seja construtivo para as pessoas que dele participam. Segundo a autora, a qualidade de nossas vidas está ligada aos relacionamentos interpessoais que estabelecemos. Faz-se um convite à reflexão sobre as condutas adotadas no cotidiano, nas relações terapeuta-cliente e nas relações com pessoas com as quais se convive, e ainda, discute-se as habilidades que se pode desenvolver para que essas relações sejam bem-sucedidas.

Nessa obra, o leitor defronta-se com o exercício da busca de si mesmo, perfazendo um caminho próprio, uma viagem ao seu mundo interior. Nesse exercício, a leitura proporciona busca e verificação interna da pessoa que lê, das ferramentas de que dispõe para entrar em sintonia com o outro.

Há uma organização na obra que serve de orientação a todos e, sobretudo, de ajuda àqueles que iniciam uma caminhada como terapeutas humanistas, pois o livro é escrito de forma didática e objetiva. Para um iniciante, o livro Encontro é como água no deserto, pois mata a sede de caminhos a seguir, com informações necessárias, práticas, teóricas e de alguma forma filosóficas da terapia humanista-existencial. Encontro enfoca de maneira vívida e sistemática muitos dos elementos básicos da relação interpessoal, não apenas no âmbito terapêutico, mas na vida como um todo. Nesse aspecto, a autora não poderia deixar de abordar o encontro Eu e Tu de Martin Buber e a arte do diálogo de Rogers.
Para a autora, o sentido da vida é o estar com, o encontro entre as pessoas. E para que esse encontro se torne possível, é preciso que o terapeuta desenvolva certas habilidades - entre em sintonia com o outro (cliente), responda à sua experiência para que se torne responsável pela parcela que lhe cabe e o oriente em suas ações.

A autora propõe algumas dimensões necessárias que antecedem o desenvolvimento das habilidades interpessoais, como a congruência, referindo-se à possibilidade de a pessoa ser genuína, a aceitação quase incondicional e a empatia. Tais habilidades são como uma pintura, vividas e desenvolvidas de acordo com cada encontro. $\mathrm{O}$ encontro não é uma prática psicológica. Não é possível elaborar um manual do encontro, ele requer algumas atitudes que se tornam pré-requisitos para a possibilidade de que ele aconteça.

O livro também ilustra de forma descritiva a vereda estreita, citada por Richard Hycner e vivida pelo psicoterapeuta humanista. A autora descreve, com muita fluência, coerência e propriedade, a prática e a teoria que domina. A vereda estreita, em sua obra, é descrita pelas vivências paradoxais entre a objetividade e a subjetividade com os quais a grande maioria dos terapeutas utiliza o processo psicoterápico. Desse modo, amplia-se a visão do como fazer e caminhar nessa vereda, por meio da explicitação clara e sistematizada que a autora faz da subjetividade do terapeuta em prol da relação com o outro.

A teoria, a objetividade internalizada pelo terapeuta, pode-se configurar em um modo seu de ser, podendo ser aplicada a todas as relações humanas. A esse respeito, a autora afirma apropriadamente na introdução, que se faz necessário casar arte e técnica por meio de uma abordagem sistemática. Assim, encontra-se no livro uma harmonia metodológica entre habilidades técnicas e humanas feitas com sensibilidade, criatividade e intuição.

Ainda na introdução, a autora assinala que é preciso construir relações positivas acreditando no potencial de auto-realização do indivíduo, que muitas vezes se desu- 
maniza. Por meio do desenvolvimento de condutas humanas e de habilidades interpessoais, pode-se ajudar reumanizar o ser humano que se desumanizou no decorrer do tempo, ou humanizar aquele que nunca foi verdadeiramente humano.

No capítulo relativo à Genealogia das habilidades interpessoais, apresenta-se alguns princípios básicos da visão humanista. De acordo com a autora, muitos são os aspectos que determinam ou são determinados pelos relacionamentos que se estabelecem com as pessoas. Para isso, selecionou cinco ramos essenciais que formam a base teórica e filosófica da proposta do livro e que permitem a compreensão das relações interpessoais: o sistema de crenças, as emoções, a cadeia pensamento - sentimento desejo - ação, a inteligência emocional e a auto-estima.

Algumas condutas essenciais à construção das relações humanas são tratadas no capítulo Checando posturas internas. A autora fala do desenvolvimento de relações construtivas por meio das habilidades. Segundo Feldman, atitudes humanistas só são desenvolvidas por aqueles que as têm em alto nível, não há como aprender ou treinar ser humanista; as atitudes humanistas apenas podem ser organizadas e identificadas. A autora faz com que o leitor se volte para si e avalie propósitos internos e a disponibilidade para utilizá-los, elucide o encontrar-se, ou seja, o encontro do humano pertencente ao leitor.

A abordagem humanista sistematizada no livro é apresentada de forma simples, sem muitas mistificações e erudição. Trata-se de habilidades interpessoais no relacionamento humano, pois, de acordo com Feldman, nem sempre é possível colocá-las em prática da mesma maneira como a descrita no livro. Há uma tentativa de organizar o que é geralmente desorganizado, de ordenar o que desordenado.

Ao longo da obra, Feldman sistematiza as habilidades interpessoais, que são divididas em quatro grupos principais: o encontro como processo, habilidade - aprendizagem formal e informal, encontro, princípios que regem os encontros. Esses grupos foram subdivididos em grupos menores: sintonizar, responder à experiência, responsabilizar e orientar, descritos minuciosamente no livro.

O livro é permeado ainda por citações e poemas de Rubem Alves, Lya Luft, Fernando Pessoa, Adélia Prado, Carlos Drummond, José Saramago e Guimarães Rosa, dentre outros, e tornam a leitura ainda mais agradável. Por serem citações e poemas contextualizados com o assunto tratado, servem de ilustração e embasamento que facilitam o entendimento da obra pelo leitor.

A conclusão do livro dá-se de maneira ímpar. A autora sugere a pergunta - o que você escuta quando escuta? - a doze diferentes psicoterapeutas, com o intuito de ilustrar de forma sintética a questão abordada em todo o texto, que é o escutar a fala do cliente.

A autora consegue prender a atenção do leitor pela forma com que escreve, estabelecendo um contato de proximidade. Ela faz o que propõe no livro - utiliza suas habilidades interpessoais para estabelecer uma relação íntima com seus leitores. Não há dúvida de que a autora é uma artista, capaz de ir além de sua experiência como psicóloga. Revela-se de forma transcendente, coesa; parte de sua essência, sua pessoa, pois escreve com alma, coração e muita inteligência.

A linguagem usada é acessível ao público leigo. Os temas abordados são extremamente importantes e atuais. Os capítulos estão concatenados, de maneira que o que falta em um se encontra no outro. O texto provoca avidez de leitura, prende a atenção. Em certos momentos é poético, em muitos, reflexivo e, talvez mais importante que tudo, informativo.

\section{Referências Bibliográficas}

Feldman, C. (2004). Encontro: uma abordagem humanista. Belo Horizonte: Crescer.
Recebido em 08.02.2008 Aceito em 05.05.2008 